INDEPENDENT JOURNAL OF MANAGEMENT \& PRODUCTION (IJM\&P)

http://www.ijmp.jor.br

v. 7, n. 5, Special Edition IFLOG 2015

ISSN: 2236-269X

DOI: 10.14807/ijmp.v7i5.457

\title{
RATIONALIZING TRANSPORTATIONS SERVICE: A CASE STUDY ON THE STANDARDIZATION OF LOGISTICS SERVICE \\ PROVIDERS
}

\author{
Clayton de Oliveira Pires \\ Federal Institute of São Paulo - Suzano Campus, Brazil \\ E-mail: Clayton.pires@ifsp.edu.br \\ Leonardo Botossi Ciomini \\ Universidade Federal de Itajubá, Brazil \\ E-mail: leonardociomini@gmail.com \\ Leonardo Gaifato Leite \\ Senac, Brazil \\ E-mail: leonardo.gaifato@gmail.com
}

Submission: $31 / 03 / 2016$

Accept: 31/03/2016

\section{ABSTRACT}

Due to high competitiveness on supply chains, small economies tend to become very important to overall costs reduction and represent marketing gains. The aim of this study is to analyze if the rationalization in low value deliveries, lower than $R \$ 2,000.00$, will be able to generate a considerable cut of costs. To perform this exploratory study, company historic was analyzed and surveys were performed with several suppliers. The studies showed it is possible to reduce freight average impact in relation to the sold value at $44.03 \%$. This result points to the advantages in coordinating more rationally the process of hiring transportation providers.

Keywords: Logistics, Transportation, Costs. 


\section{INTRODUCTION}

Outsourcing and logistics are questions that have always been at the core of management. Nicolau Maquiavel in his classic "The Prince" wrote a chapter about outsourcing, in which he discussed the use of mercenary soldiers for power conquest. At the same time the "Great Navigations" that had been stimulated to find more advantageous routes both economically and by time and distance issues, redraw the world map. Optimization of logistical resources is an issue that will compose the management core.

Good logistics management represents an important competitive advantage for any company in current globalized economic environment, where competition for market no longer happens among companies but among global supply chains. Due to the size these chains can achieve, the efficient use of internal and external services is a major competitive advantage.

Company $X$ operates in the personal and collective protective equipment segment (PPE and CPE, respectively) with headquarters in São Paulo and Campo Limpo Paulista, serving the internal market and distributing its products along the national territory. Its distribution strategy is to deliver in Greater São Paulo with its own fleet and in other regions doing partnerships with outsourced fleets. This strategy generates a huge demand for service providers, but these companies have a great heterogeneity in several respects with, for instance, fleets, uniforms, cost, level of service, punctuality, reliability.

The process of contracting services does not follow any pre-established policy. Whenever the need to hire a delivery arises, the company makes a quotation process among registered providers, these providers add up to 38 currently. Besides taking time of the department due to buying by the use of physical, financial and human resources, this process leads to the loss of bargaining power justified by the non-adoption of a strategy to hire a large volume of deliveries, however hiring delivery service within the current system allows to take the best current freight price. This scenario points to a key question: will there be a reduction in transportation costs with a rationalization of freight hiring process?

The number of customers served by the company is approximately 700 , with very different order values and it is part of the company policy to divide them into 
higher and lower than $R \$ 2,000.00$. This work will be limited to study the deliveries of invoices lower than $R \$ 2,000.00$, because delivery represents a high percentage of costs in such cases.

The aim of this study is to analyze how relevant the financial importance is in rationalizing the management of the delivery service hiring process in a PPE and CPE company and which benefits can be achieved when those aspects are practiced.

To conduct the case study a direct survey conducted in the company deliveries process will compose the database, involving sprayed deliveries between the months of April and September 2014. These data will be compared with hiring services quotes in order to perform a large number of prefixed deliveries, which will confirm or deny the efficacy of the new transportation management policy here proposed.

To this end, the present study will have a division into eight sections, where the first is this introduction presenting the topic, the research problem, its justification, general and specific objectives, and methodology. The second section discusses the theoretical framework considering logistics concepts and the primary and secondary activities. The third part will address the concept of transportation performing a comparative analysis in respect to the modal ones. Logistics costs and costing systems will be presented in the fourth chapter. The fifth section deal with the methodology used in the case study. The sixth section is the case study itself. The seventh one will present the conclusions and the final section contains the bibliography that supported the study.

\section{THEORETICAL FRAMEWORK}

\subsection{Business Logistics}

Logistics plays an important role in organizations in the industrial, commercial and service. Studies in the area began in the military field, even though its use dates back to the beginning of civilization.

Ballou (2014) points that business logistics does not mean the same thing for everyone, even for specialists. So far, the field does not have a single title to identify it, as did marketing and production sectors. Also according to the author, a sample of 
DOI: $10.14807 /$ ijmp.v7i5.457

the embers from the National Council of Physical Distribution Management in America identified that the area is represented by names such as transportation, distribution, physical distribution, supply and distribution, materials management and operations.

Santos, Botinha and Leal (2013) expand this concept stating that, considering the logistics process, besides covering from the initial stage, starting from raw materials to product delivery to the consumer, it is possible to extend the studies beyond that point and analyze the inverse flow of traditional chain, ie, the product going from the final consumer to its re-use, thereby avoiding improper disposal in the environment. Thus, the authors extend the definition of business logistics adding the idea of reverse logistics.

According to Ferri, Chaves and Ribeiro (2015) logistics is very wide and there is a multitude of processes from prospecting the raw material in nature to the final consumer. With a strong trend of product to return to the production system after ending its consumption, there are plenty of improvements and economic and productivity gains. These activities are grouped in many ways, however, for this work, primary and secondary activities division pattern will be adopted, as work Oliveira and Leite (2010).

Ballou (2014) defines primary activities as the key activities of the logistics process, the most important ones in this business environment and, in addition, those participating with the highest logistics costs rates. They are transportation, inventory maintenance and order processing.

Silveira (2013) states secondary or support activities aims to support the primary activities, in order to meet completely the aim of reducing distances between demand and production, for the perfect customer satisfaction. This correlation between primary and secondary activities aiming at a good level of service is exemplified in Figure 01.

Miranda et. al. (2014) consider that although transportation, inventory maintenance and order processing are the main items contributing to the availability and physical condition of goods and services, there is a number of other activities that support these primary activities. They are Storage, Material Handling, Protective 
DOI: $10.14807 /$ ijmp.v7i5.457

Packaging, Obtainment, Products Program, information Maintenance (BALLOU, 2014).

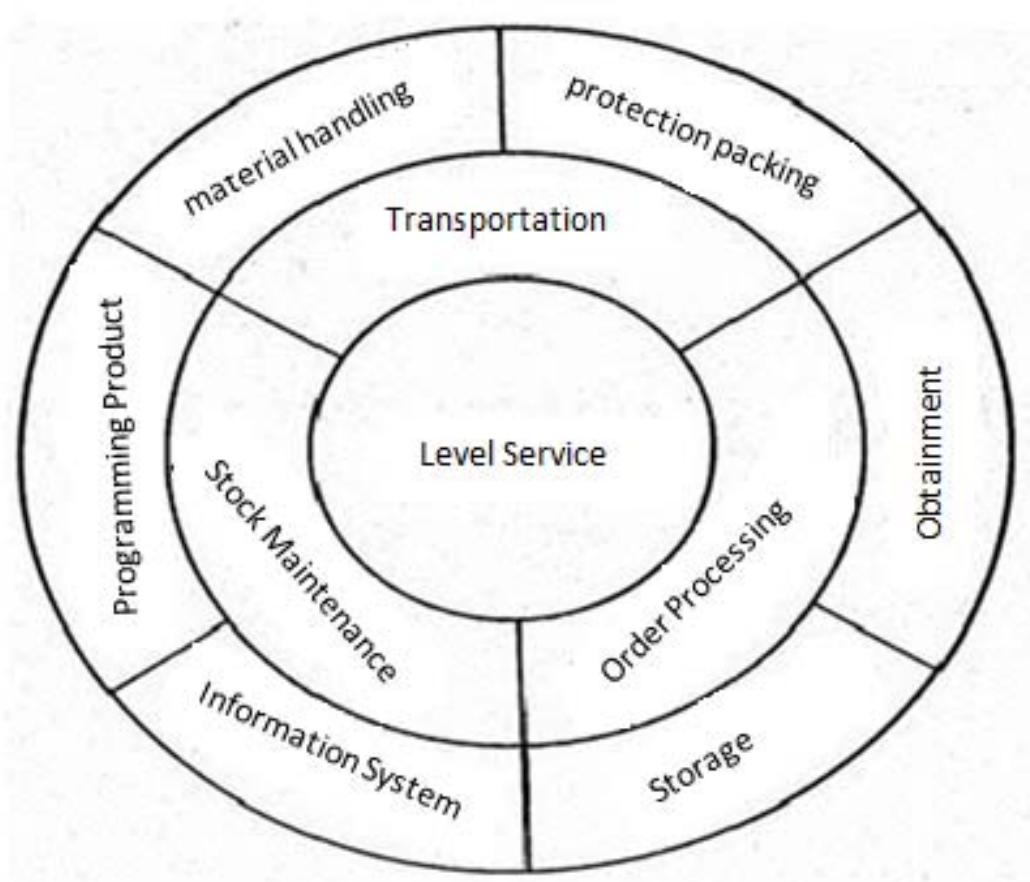

Figure 01: Relationship between primary and support activities with the level of service desired

Source: Ballou (2014)

\subsection{Transportation}

Braga and Castillo (2013) allege that in the last two decades of increasingly systematic way, logistics has been discussed and disseminated in Brazil, just as happens in other countries, especially the United States and Europe since late 1980s. It is clear the association between logistics and globalization, and so it is clear its adoption by large business organizations concerned with better functional integration of productive chains. Logistics is establishing itself as a real sector of the economy, industry associations and logistics services quality certification institutions gain strength while the activity is consolidated and diversified.

According to Nogueira (2012), transportation is the main component of the logistics system, because all products involve transportation from place to place, until they are in its customers' hands. Transportation activity allows several traffic routes combinations, each of them with particular performance characteristics. The choices of transport have a strong impact on the responsibility and supply chain efficiency. 
Transportation plays a major role in the quality of logistics services, as it affects directly on delivery time, reliability and product safety.

Modal logistics are the transportation means used to ensure the flow of materials. According to Vitorino (2013, p. 13), each kind of transportation offers a different combination of speed, cost, availability and capacity. Salgado (2013, p.82) states that the modals used to make a delivery can be: a) road - the charge is carried by road in trucks, etc; b) rail - the charge is carried by rail in boxcars, platforms, etc.; c) Waterway - the charge is carried in ships across the seas, oceans, rivers, lakes or ponds; d) air - the charge is transported in airplanes through the airspace; e) pipeline - always in the form of dry bulk, liquid or gaseous - the charge is transported through pipelines.

According to Souza and Markoski (2012) our country suffers from the format that was thought many years ago, through incentives for car companies which participated in the exploration of a single transportation means, coincidentally the second most expensive, the road transportation. Brazil follows a cast format, which works channeled in an area prone balancing with the new logistics operations promoted by logistics operators that constantly seek the integration of different means of transportation, aiming at a more efficient transportation management with lower costs.

\subsection{Logistic Costs}

In a country with continental dimensions like Brazil, the market's main target is to generate the lowest possible cost to maintaining the sustainability of productive activities (MINADEO, 2012).

Vasconcelos and Marins (2008) argue that with intensified competition and the increasing scope of global markets, organizations have realized the failure to improve only internal performance, and with it ,the need for the entire chain in which they are inserted become competitive and integrated. To this end, the links involved should explore all of their abilities in the pursuit of superior performance, because competition no longer occurs among companies, but among chains (SOUZA; LEMOS; ZORZO, 2014).

With the logistics participating in different parts of commodity production chain, it presents significant costs that, if well managed, positively alter the level of 
competitiveness of enterprises. So, we need to assess these added costs seeking the real importance of their participation in the constitution of logistics costs, so that it is possible to make a decision (PINK; OLIVEIRA, 2010).

Thus it is easy to see that management costs are one of the factors capable of providing competitiveness directly to the organization, either through the production of goods and/or provision of services with costs lower than those which competitors can manage (PIANA; ERDMANN, 2011).

For Christopher (2007), the source of competitive advantage of a company happens first by the ability to differ themselves from the others and, subsequently, to operate with lower costs. Also in this line Lopes et. al. (2013) refutes that it is not only controlling costs, these should be quantified so they can be properly managed.

Souza and Pires (2014) very the verification problems about logistics management costs by summing them up in: knowledge lack about real costs, listing of a high aggregation degree costs, and use of assessment systems based on overall costs.

For Lunkes and Canny (2012), the understanding of cost concepts are essential for any company that aims to take a correct decision regarding business opportunities. Also in this context, Kaminski (2004) corroborates exemplifying that management of logistics costs is useful for assisting the correct resources allocation, stock control, decisions on outsourcing, costs and level of service, bottlenecks elimination, system performance evaluation and improvement of processes.

\section{METHODOLOGY}

This work has its methodology based on two different stages. The first one consists in the literature review, in order to base all content here discussed, and thus provide, clearly, an understanding on factors related to logistics processes of the studied company that, for ethical reasons, from now on it will be referred to as company $\mathrm{X}$.

The second part is the case study. Gil (1995) cited by Ventura (2007) infers that the case study does not accept a hard route for its delimitation because each situation has its uniqueness, but it is possible to set four distinct phases that normally 
structures this kind of study: a) case delimitation; b) data collection; c) data selection, analysis and interpretation and d) report writing.

Ventura (2007) explains these stages as follows. The first stage is to define the object of study, from the areas to be studied effectively to the selection of data necessary for the understanding. The second phase is data collection itself, made by quantitative and qualitative methods defined in the previous step. Such methods may include observation, analysis of documents, interviews, questionnaires, data collection, etc. The third step is the understanding, i.e., represents data selection, analysis and interpretation. Finally, the fourth stage is where the study ends up with the development of partial and/or final reports.

For this author, the main advantages and applications of case study are for exploratory research because its flexibility is recommended in the preliminary stages of research, especially in complex subjects, which helps in building hypotheses or reformulation of the problem. This flexibility also favors the study to reach deeper aspects of the problem.

This study will confront a company $X$ database, concerning the period from April to September 2014, where the process of hiring transportation service was held individually with the best cost for hiring a large number of deliveries. This confrontation will determine which fleet management policy is more efficient from a financial point of view. To this end, the theoretical study on the subject discusses the relevant aspects in the management process. Employees responsible for the delivery management were interviewed in order to generate data about the company and processes

\section{CASE STUDY}

\subsection{Brief History Of The Company}

The Industry and Commerce $\mathrm{X}$, which operates in the personal and collective protective equipment segment (PPE and CPE, respectively) has its headquarter in the East Zone of São Paulo, with $2500 \mathrm{~m}^{2}$ and plant unit in Santa Catarina, with about 400 employees and three Distribution Centers serving the whole national territory.

It was founded in 1966 with the uniforms and professional clothing factory. In the 1990s, it started to produce PPEs, and later, protective equipment for work on 
DOI: $10.14807 /$ ijmp.v7i5.457

energized and confined network spaces, always investing in the latest technology and having a team of highly skilled professionals, this way becoming a reference in the segment and gaining renowned customers nationwide. Company $\mathrm{X}$ has achieved a range of about 10,000 items that meet the most stringent current regulations, such as NR10, NR18 and NR33 and is recognized in the market due to its safety and reliability.

\subsection{Current Scenery Of Deliveries Management}

\subsubsection{Stock And Services Level}

It is of common sense that when the topic is stock control, with respect to the optimal amounts to be maintained, there is controversy because the decision must take into account the financial aspect and the physical space that each company has available for stocking products when it occurs in its own facilities, such as the company $\mathrm{X}$.

On the one hand, to maintain high stock levels beyond the necessary brings the need for a cash amount stored too, without immediate turnover and without the advantages of applying the value in a financially profitable option, for example.

On the other hand, not keeping stocks may - in addition to possibly cause bottlenecks in production - generate slowness in sales process and in revenues, and delays in meeting the customer needs.

According to Ballou (2014) the storage of goods predicting its future use requires investment by the organization. Ideally, the perfect synchronization between supply and demand, in order to make the maintenance of unnecessary stock.

Considering the above aspects, the ideal is to have a middle ground, ie, a minimal stock preparation that meets the needs of a specific period, without keeping impressive amounts stocked, what ends up becoming "idle" for a certain period in which that raw material and/or product will not be needed.

To calculate the point of functional minimum stock, computerized tools appropriate to planning, involving sales, PCP, production and turnovers are necessary. It is also very important the optimization process of stocks, analysis of the items consumption history, and midpoint of sales, given that the current situation of 
DOI: $10.14807 /$ ijmp.v7i5.457

most industries is uncertain. The company makes use of DataSul production and logistics management system.

Company $X$ prioritizes the quick service to the main clients, agility from the customer order, until the time this gets his purchase. For this to occur, the company hires carriers practically for every order without fractionate the charge or dilute it.

Currently, for not having so many delays in orders deliveries, company $X$ also maintains a stock level considered high based on the purchase history of each customer, which can meet most of the requests immediately. Based on the report and on $A B C$ curve analysis, customers that generate higher profitability have priority, with almost immediate delivery.

Other customers are engaged in the production list and when the company do not serve them immediately, they can do it within an average of 15 days, time required for the invoice of the items are missing or not enough in stock to make the orders. Special items with low sales history are in the store only for simple orders, and the customer is aware that these products will have a longer delivery time, so storage space is increased to keep only the most consumed items.

Figure 2 illustrates a comparison of delivery deadlines in relation to total deliveries in the trimester August to October 2014, and points out that even conducting strategic analysis and counting on a team of 12 trained professionals in the planning department, it is not possible yet to get a minimum safety stock so that there are no blockages in the production and, consequently, delays in delivery deadlines.

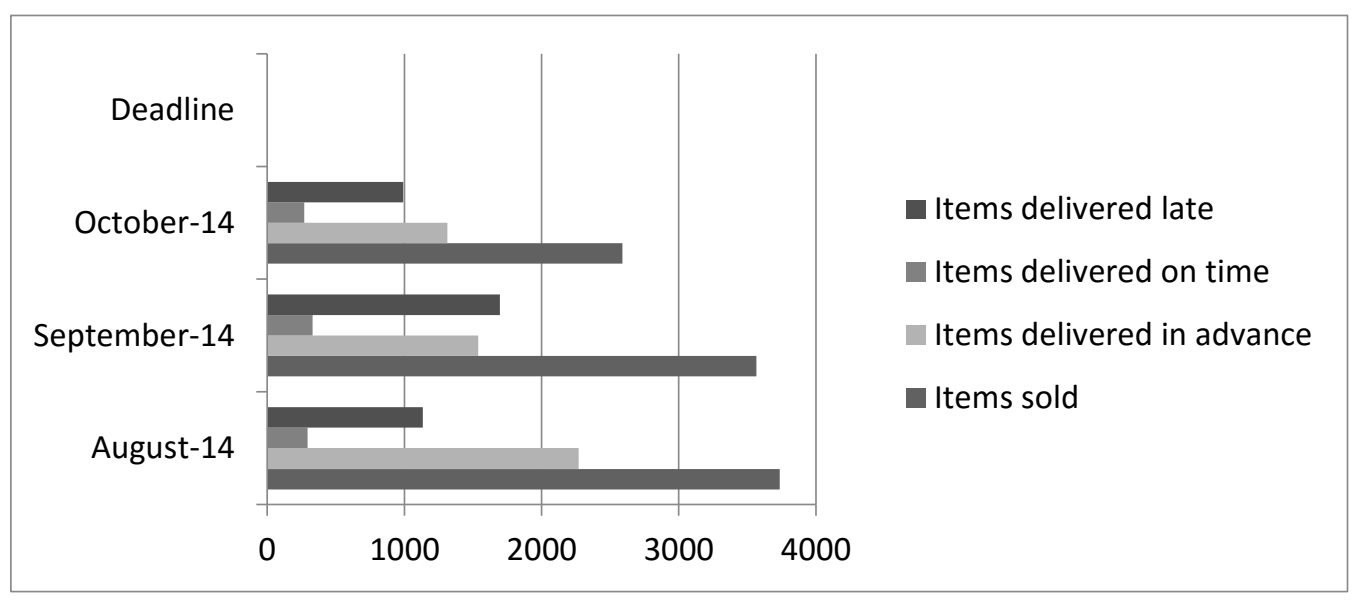

Figure 2: Delivery deadlines 
DOI: 10.14807/ijmp.v7i5.457

\subsubsection{Transportation}

In the logistics chain transportation essentially important, since logistics is a process that includes criterions planning so that products/services are available where and when needed, satisfying its users (customers).

The management of third-party-contracted transportation function is different from the movement performed by own fleet. For contracted services, negotiation of freight, documentation, audit and consolidation of freight are relevant issues. For the own transportation, dispatch, charge balancing and routing are other issues that must be managed. Often the traffic manager must deal with a mix of own transportation and third party ones. (BALLOU, 2014).

Logistics process involves all stages, from procurement of materials to final product delivery, production, storage, distribution and transportation. The ideal thing is that this process occurs naturally, without interruptions or bottlenecks. In the case of company $\mathrm{X}$, the random way to work with third-party deliveries, causes some wear on service levels and, especially, in drafting freight routes, which impacts directly on the supply chain development.

Serving the internal market and distributing its products throughout the national territory, Industry and Trade $X$ has a small own fleet of eight vehicles that are used for emergency services in the company's work routine, not only for supplies, but also for emergency raw materials removal, products in service (reverse logistics) alike ones, in neighboring towns.

The company's policy is to divide delivery costs in upper and lower than $\mathrm{R} \$$ $2,000.00$, however there are no rules for hiring freight, always performing quotes delivery by delivery. This method ends up raising the cost since it does not have the advantage of scale contract, which naturally, conforming to market rules, would decrease cost. Company $\mathrm{X}$ performs quotations among the 38 companies registered, the lowest price takes the service, and it is common practice the correlation one invoice/one delivery.

The company practices the CIF delivery model, which is an acronym for Cost, Insurance and Freight. In this type of freight, the supplier is responsible for all costs and risks to goods delivery, including insurance and freight. This responsibility ends when the goods arrive at the destination point designated by the buyer. 
INDEPENDENT JOURNAL OF MANAGEMENT \& PRODUCTION (IJM\&P)

DOI: 10.14807/ijmp.v7i5.457

Deliveries of invoices lower than $\mathrm{R} \$ 2,000.00$, despite being laborious due to the large volume and lesser profit offered due to financial figures, have strategic importance in maintaining customer portfolio. Considering these circumstances, it is up to company $\mathrm{X}$ seek a better way to manage this service.

The number of customers served by the company in the period from April to September 2014 was 698 . This case study will focus on the 10 main customers which represent only $1.43 \%$ of all companies served, having a semester revenue of $R \$ 15,523,165.24$ from the total $R \$ 40,422,899.20$. The number of deliveries of this group is 1,615 from the total 4,241 , of these, 624 deliveries are values lower than $R \$$ $2,000.00$ from a total the 1710 services in these conditions. The Delivery Total Cost (CTE) is $R \$ 756,278.37$, however, the 10 main customers group accounts for $R \$$ $316,000.32$ of this expenditure, as pointed Table 01: Data from April to September 2014.

Table 01: Data from April to September 2014

\begin{tabular}{|c|c|c|c|c|}
\hline CLIENTS & $\begin{array}{l}\text { TOTAL VALUE OF } \\
\text { INVOICES }\end{array}$ & $\begin{array}{l}\text { AMOUNT } \\
\text { OF } \\
\text { INVOICES } \\
\text { LOWER } \\
\text { THAN < R } \$ \\
2000,00\end{array}$ & $\begin{array}{c}\text { TOTAL } \\
\text { AMOUNT OF } \\
\text { INVOINCES }\end{array}$ & $\begin{array}{l}\text { TOTAL COSTS } \\
\text { OF DELIVERIES }\end{array}$ \\
\hline Client A - Petroleum & $\mathrm{R} \$ \quad 7.557 .173,09$ & 142 & 432 & $\mathrm{R} \$ 124.352,87$ \\
\hline Cliente B - Metallurgy & $\begin{array}{ll}\mathrm{R} \$ & 1.610 .724,87 \\
\end{array}$ & 32 & 156 & $\mathrm{R} \$ \quad 18.543,92$ \\
\hline Client C-Telecommunication & $\mathrm{R} \$ \quad 1.568 .373,77$ & 11 & 77 & $\mathrm{R} \$ \quad 33.466,39$ \\
\hline Client D - Technology & $832.749,12$ & 17 & 140 & $\mathrm{R} \$ \quad 47.135,16$ \\
\hline Ciente E - Electric Power & $811.962,31$ & 7 & 41 & $\mathrm{R} \$ \quad 8.144,29$ \\
\hline Client F - IPE's e CPE's & $793.858,24$ & 21 & 59 & $9.250,44$ \\
\hline Client G - Food Industry & $790.868,98$ & 113 & 233 & $\mathrm{R} \$ \quad 28.557,57$ \\
\hline Client $\mathrm{H}-$ Gas & $547.116,99$ & 51 & 128 & $\mathrm{R} \$ \quad 17.481,35$ \\
\hline Client I - Beverage Industry & $535.323,36$ & 221 & 324 & $\mathrm{R} \$ \quad 23.246,74$ \\
\hline Client $\mathrm{J}$ - Electric Power & $475.014,51$ & 9 & 25 & $5.821,59$ \\
\hline Top 10 clients & $\mathrm{R} \$ 15.523 .165,24$ & 624 & 1.615 & $\mathrm{R} \$ 316.000,32$ \\
\hline OTHERS $688 \mathrm{C}$ & $\mathrm{R} \$ 24.899 .733,96$ & 1.086 & 2.626 & $\mathrm{R} \$ 440.278,05$ \\
\hline TOTAL & $\mathrm{R} \$ 40.422 .899,20$ & 1.710 & 4.241 & $\mathrm{R} \$ 756.278,37$ \\
\hline
\end{tabular}

The 10 main customers represent $38.40 \%$ of total sales, with the average percentage $2.04 \%$ of freight cost in relation to the invoiced against an average percentage of $1.77 \%$ of the remaining 688 . In relation to the Delivery Total Costal (CTE), the main companies represent $41.78 \%$ of total expenditure, a fact that illustrates how improvements on this small group servings processes can represent great savings in transportation. Invoices lower than $R \$ 2,000.00$ are approximately 38.64\%, as shown in Table 02: Analysis of data from April to September 2014. 
Table 02: Analysis of data from April to September 2014.

\begin{tabular}{|l|c|c|c|c|}
\hline CLIENTS & $\begin{array}{c}\text { \% COMPARED } \\
\text { TO TOTAL } \\
\text { INVOICED }\end{array}$ & $\begin{array}{c}\text { \% OF } \\
\text { FREIGHT IN } \\
\text { RELATION TO } \\
\text { TOTAL } \\
\text { INVOICED }\end{array}$ & $\begin{array}{c}\text { \% FREIGHT IN } \\
\text { RELATION TO } \\
\text { THE VALUE } \\
\text { OF THE } \\
\text { TOTAL COST } \\
\text { OF DELIVERY }\end{array}$ & $\begin{array}{c}\text { OF OF } \\
\text { INVOICES } \\
\text { LOWER } \\
\text { THAN R\$ } \\
2000\end{array}$ \\
\hline Client A - Petroleum & $18,70 \%$ & $1,65 \%$ & $16,44 \%$ & $32,87 \%$ \\
\hline Cliente B - Metallurgy & $3,98 \%$ & $1,15 \%$ & $2,45 \%$ & $20,51 \%$ \\
\hline Client C - & $3,88 \%$ & $2,13 \%$ & $4,43 \%$ & $14,29 \%$ \\
\hline Telecommunication & $2,06 \%$ & $5,66 \%$ & $6,23 \%$ & $12,14 \%$ \\
\hline Client D - Technology & $2,01 \%$ & $1,00 \%$ & $1,08 \%$ & $17,07 \%$ \\
\hline Ciente E - Electric Power & $1,96 \%$ & $1,17 \%$ & $1,22 \%$ & $35,59 \%$ \\
\hline Client F - IPE's e CPE's & $1,96 \%$ & $3,61 \%$ & $3,78 \%$ & $48,50 \%$ \\
\hline Client G - Food Industry & $1,35 \%$ & $3,20 \%$ & $2,31 \%$ & $39,84 \%$ \\
\hline Client H - Gas & $1,32 \%$ & $4,34 \%$ & $3,07 \%$ & $68,21 \%$ \\
\hline Client I - Beverage Industry & $1,18 \%$ & $1,23 \%$ & $0,77 \%$ & $36,00 \%$ \\
\hline Client J - Electric Power & $38,40 \%$ & $2,04 \%$ & $41,78 \%$ & $38,64 \%$ \\
\hline Top 10 clients & $61,60 \%$ & $1,77 \%$ & $58,22 \%$ & $41,36 \%$ \\
\hline OTHERS 688 CLIENTS & $100 \%$ & $1,87 \%$ & $100 \%$ & \\
\hline TOTAL & Source Direct survey $(2015)$ & & \\
\hline
\end{tabular}

The company serves throughout the country, however, the 10 companies object of this study do not order deliveries only in the states of Tocantins, Acre and Rondônia, all located in the northern region. As the cost of freight is correlated, in addition to weight and volume, distanced, there will not be the need to deliver low values in these states. This represents a simplification in the process. Most major customers need servings in many states, as shown in Table 03: Locations served from April to September 2014.

Table 03: Locations served between April and September 2014

\begin{tabular}{|l|c|c|}
\hline \multicolumn{1}{|c|}{ CLIENTS } & $\begin{array}{c}\text { STATES } \\
\text { ASSISTED }\end{array}$ & $\begin{array}{c}\text { REGIONS } \\
\text { ASSISTED }\end{array}$ \\
\hline Client A - Petroleum & 15 & 4 \\
\hline Client B - Metallurgy & 4 & 2 \\
\hline Client C - Telecommunication & 15 & 3 \\
\hline Client D - Technology & 1 & 1 \\
\hline Client E - Electric Power & 2 & 1 \\
\hline Client F - IPE's e CPE's & 6 & 4 \\
\hline Client G - Food Industry & 10 & 4 \\
\hline Client H - Gas & 10 & 3 \\
\hline Client I - Beverage Industry & 19 & 5 \\
\hline Client J - Electric Power & 1 & 1 \\
\hline Top 10 clients & 24 & 5 \\
\hline OTHERS 688 CLIENTS & 27 & 5 \\
\hline TOTAL & & \\
\hline
\end{tabular}


INDEPENDENT JOURNAL OF MANAGEMENT \& PRODUCTION (IJM\&P)

http://www.ijmp.jor.br

v. 7, n. 5, Special Edition IFLOG 2015

ISSN: 2236-269X

DOI: 10.14807/ijmp.v7i5.457

Table 04: Descriptive from April to September 2014 presents data concerning to invoices lower than $R \$ 2,000.00$. The amount of invoices in these conditions is 1,710 , which represents a percentage of $40.32 \%$ of the total, but represents only $3.46 \%$ of the revenue with $R \$ 1,400,564.80$. Delivery Total Cost is $R \$ 756,278.37$ and the CTE of invoices lower than $R \$ 2,000.00$ is $R \$ 138,360.30$ generating a representation of $18.29 \%$ of these expenses.

The CTE percentage of invoices lower than $R \$ 2,000.00$ is very high, especially when compared to its financial representatives. The Average Delivery Total Cost for invoices lower than $R \$ 2,000.00$ during the studied period was $R \$$ 80.91 , this value will be the reference to propose the impasse solution of the costs reduction in the next sessions of this course completion work.

Table 04: Descriptive from April to September 2014

\section{DESCRITIVO DE ABRIL À SETEMBRO}

TOTAL

\begin{tabular}{|l|l|}
\hline Amount of invoices & 4241 \\
\hline Total Value of Invoices & $\mathrm{R} \$ 40.422 .899,20$ \\
\hline Total Cost of Delivery & $\mathrm{R} \$$ \\
\hline Amount of Invoices Lower than $\mathrm{R} \$ 2000,00$ & 1710 \\
\hline Total value of Invoices Lower than $\mathrm{R} \$ 2000,00$ & $\mathrm{R} \$ \quad 1.400 .564,80$ \\
\hline Total Cost of Delivery for Invoices Lower than $\mathrm{R} \$ 2000,00$ & $\mathrm{R} \$ \quad 138.360,30$ \\
\hline Invoices Lower than $\mathrm{R} \$ 2000,00(\%)$ & $40,32 \%$ \\
\hline Representativeness of invoices lower than $\mathrm{R} \$ 2,000.00$ in the billing & $3,46 \%$ \\
\hline $\begin{array}{l}\text { Representativeness of the total cost of delivery with lower invoices than } \mathrm{R} \$ \\
2,000.00\end{array}$ & $18,29 \%$ \\
\hline Total cost of delivery with lower invoices than $\mathrm{R} \$ 2,000.00$ & $\mathrm{R} \$$ \\
\hline Average value of the lower Invoices to $\mathrm{R} \$ 2,000.00$ & $\mathrm{R} \$$ \\
\hline \multicolumn{1}{|c|}{ Source: Direct survey $(2015)$} & 819,04 \\
\hline
\end{tabular}

\section{ACTION PROPOSAL FOR DELIVERIES COST REDUCTION OF INVOICES LOWER THAN R\$2,000.00}

Based on the absence of a more effective policy for hiring transportation, the rationalization process will generate significant cost savings and, consequently, increase the company's profit.

During the studied period, there were 38 suppliers in the register of service providers who participated in the prices every time there was delivery, generating 4,241 total quotations, 1710 quotations of invoices lower than $R \$ 2,000.00$, of these, 624 represented the 10 largest customers group. 
DOI: 10.14807/ijmp.v7i5.457

The project should start as a pilot to meet the 10 largest customers. The proposal to improve the costs is negotiating with carriers making deals with freight values for a considerable amount of deliveries, gaining in scale economy.

In order to project the demand to provide the basis for the negotiation of a new transportation management model, it will be used the reference value for the contract to delivery service providing to 500 freight in six months. Although the demand was 624deliveries during the period used as reference, it is safer to use a lower basis and if it exceeds the goal, the amounts to be paid will be already calculated.

The aim is to deal with just one carrier to perform the service of the 10 largest customers, so it is possible to keep a closer relationship with this supplier, it will facilitate charges traceability and the expectation of improving the relationship with end customers.

Assuming that the values of deliveries will be traded only once every six months, besides savings generated by rationalization, there will be a considerable decrease in the acquisition cost of that service.

The 10 largest customers have delivery addresses in 24 states, in all regions, totaling 417 addresses, 94 in capital and 323 in the inner cities as shown in Table 05. The Southeast and South have the highest shares, $58.27 \%$ and $23.50 \%$ respectively totaling $81.77 \%$ of delivery addresses.

Due to the high-added value of protective equipment, a small volume of items generates a high invoice, for instance, a pair of safety gloves para-aramid costs $R \$$ 56.80 , with an average weight of 480 grams, is sold in $50 \mathrm{~cm} \times 50 \mathrm{~cm} X$ boxes $50 \mathrm{com}$, with 35 units, with the final value of $R \$ 1,988.00$ and weighing $16.8 \mathrm{~kg}$.

To simulate this, average loads will have as average invoice value $R \$$ $1,000.00$ and average weight of $20 \mathrm{~kg}$. It is noteworthy that in sales history there are several invoices lower than $\mathrm{R} \$ 50.00$ and the average value of invoices lower than $R \$ 2,000.00$ is $R \$ 819.04$, which makes these parameters very assertive for the following projections .

\subsection{Post-Rationalization Projections Of Transportation}

After requesting quotations with some companies, the purpose contained in Table 05 was obtained for carrying out deliveries in all states needed to meet the 10 
INDEPENDENT JOURNAL OF MANAGEMENT \& PRODUCTION (IJM\&P)

http://www.ijmp.jor.br

v. 7, n. 5, Special Edition IFLOG 2015

ISSN: 2236-269X

DOI: 10.14807/ijmp.v7i5.457

largest customers. The table shows the freight costs having as reference a $20 \mathrm{~kg}$ load that costs $R \$ 1,000.00$.

Although there is a limitation not to be available the exact location of the destination of all deliveries lower than R2,000.00, it is possible to infer that because of $81.77 \%$ of deliveries addresses are concentrated in the southeastern and southern regions, these ratios should be maintained in carrying out cost projections.

Table 05: Delivery addresses of the 10 largest customers

\begin{tabular}{|c|c|c|c|c|c|c|c|}
\hline & \multicolumn{3}{|c|}{$\begin{array}{l}\text { proportions between the delivery } \\
\text { addresses }\end{array}$} \\
\hline Region & State & $\begin{array}{c}\text { Address for } \\
\text { deliveries }\end{array}$ & $\begin{array}{l}\text { State's } \\
\text { capital } \\
\end{array}$ & $\begin{array}{c}\text { Countryside } \\
\text { of state }\end{array}$ & $\begin{array}{l}\text { Address } \\
\text { for } \\
\text { deliveries }\end{array}$ & $\begin{array}{l}\text { State's } \\
\text { capital }\end{array}$ & $\begin{array}{c}\text { Countryside } \\
\text { of state }\end{array}$ \\
\hline central West & GO & 11 & 1 & 10 & $2,64 \%$ & $0,24 \%$ & $2,40 \%$ \\
\hline central West & MT & 8 & 1 & 7 & $1,92 \%$ & $0,24 \%$ & $1,68 \%$ \\
\hline central West & MS & 7 & 2 & 5 & $1,68 \%$ & $0,48 \%$ & $1,20 \%$ \\
\hline central West & DF & 2 & 2 & 0 & $0,48 \%$ & $0,48 \%$ & $0,00 \%$ \\
\hline $\begin{array}{c}\text { subtotal } \\
\text { central West }\end{array}$ & & 28 & 6 & 22 & $6,71 \%$ & $1,44 \%$ & $5,28 \%$ \\
\hline northeast & BA & 12 & 4 & 8 & $2,88 \%$ & $0,96 \%$ & $1,92 \%$ \\
\hline northeast & RN & 6 & 3 & 3 & $1,44 \%$ & $0,72 \%$ & $0,72 \%$ \\
\hline northeast & PE & 5 & 0 & 5 & $1,20 \%$ & $0,00 \%$ & $1,20 \%$ \\
\hline northeast & CE & 4 & 3 & 1 & $0,96 \%$ & $0,72 \%$ & $0,24 \%$ \\
\hline northeast & SE & 4 & 3 & 1 & $0,96 \%$ & $0,72 \%$ & $0,24 \%$ \\
\hline northeast & MA & 3 & 3 & 0 & $0,72 \%$ & $0,72 \%$ & $0,00 \%$ \\
\hline northeast & $\mathrm{AL}$ & 2 & 1 & 1 & $0,48 \%$ & $0,24 \%$ & $0,24 \%$ \\
\hline northeast & PB & 2 & 1 & 1 & $0,48 \%$ & $0,24 \%$ & $0,24 \%$ \\
\hline northeast & $\mathrm{PI}$ & 1 & 1 & 0 & $0,24 \%$ & $0,24 \%$ & $0,00 \%$ \\
\hline $\begin{array}{l}\text { subtotal } \\
\text { nordeste }\end{array}$ & & 39 & 19 & 20 & $9,35 \%$ & $4,56 \%$ & $4,80 \%$ \\
\hline North & AM & 4 & 3 & 1 & $0,96 \%$ & $0,72 \%$ & $0,24 \%$ \\
\hline \begin{tabular}{|l|} 
North \\
\end{tabular} & PA & 3 & 1 & 2 & $0,72 \%$ & $0,24 \%$ & $0,48 \%$ \\
\hline \begin{tabular}{|l|} 
North \\
\end{tabular} & AP & 1 & 1 & 0 & $0,24 \%$ & $0,24 \%$ & $0,00 \%$ \\
\hline \begin{tabular}{|l|} 
North \\
\end{tabular} & RR & 1 & 1 & 0 & $0,24 \%$ & $0,24 \%$ & $0,00 \%$ \\
\hline $\begin{array}{l}\text { subtotal } \\
\text { North }\end{array}$ & & 9 & 6 & 3 & $2,16 \%$ & $1,44 \%$ & $0,72 \%$ \\
\hline Southeast & SP & 190 & 43 & 147 & $45,56 \%$ & $10,31 \%$ & $35,25 \%$ \\
\hline Southeast & MG & 22 & 3 & 19 & $5,28 \%$ & $0,72 \%$ & $4,56 \%$ \\
\hline Southeast & RJ & 22 & 9 & 13 & $5,28 \%$ & $2,16 \%$ & $3,12 \%$ \\
\hline Southeast & ES & 9 & 2 & 7 & $2,16 \%$ & $0,48 \%$ & $1,68 \%$ \\
\hline $\begin{array}{l}\text { subtotal } \\
\text { southeast }\end{array}$ & & 243 & 57 & 186 & $58,27 \%$ & $13,67 \%$ & $44,60 \%$ \\
\hline South & RS & 44 & 3 & 41 & $10,55 \%$ & $0,72 \%$ & $9,83 \%$ \\
\hline South & SC & 30 & 0 & 30 & $7,19 \%$ & $0,00 \%$ & $7,19 \%$ \\
\hline South & PR & 24 & 3 & 21 & $5,76 \%$ & $0,72 \%$ & $5,04 \%$ \\
\hline $\begin{array}{l}\text { subtotal } \\
\text { South }\end{array}$ & & 98 & 6 & 92 & $23,50 \%$ & $1,44 \%$ & $22,06 \%$ \\
\hline total & & 417 & 94 & 323 & $100,00 \%$ & $22,54 \%$ & $77,46 \%$ \\
\hline
\end{tabular}


INDEPENDENT JOURNAL OF MANAGEMENT \& PRODUCTION (IJM\&P)

http://www.ijmp.jor.br

v. 7, n. 5, Special Edition IFLOG 2015

ISSN: 2236-269X

DOI: 10.14807/ijmp.v7i5.457

Table 06: Cost of hired freights

\begin{tabular}{|c|c|c|c|c|}
\hline Destination & \multicolumn{2}{|c|}{ Value per $\mathrm{kg}$} & Ad valorem on value invoices (\%) & minimum weight $20 \mathrm{~kg}$ \\
\hline SP - State's capital & $\mathrm{R} \$$ & 0,93 & 0,46 & $\mathrm{R} \$ \quad 23,22$ \\
\hline SP - Countryside & $\mathrm{R} \$$ & 0,75 & 0,20 & $\mathrm{R} \$ \quad 16,95$ \\
\hline AL - State's capital & $\mathrm{R} \$$ & 1,72 & 0,50 & $R \$ 39,31$ \\
\hline AL - Countryside & $\mathrm{R} \$$ & 1,89 & 0,50 & $\mathrm{R} \$ \quad 42,74$ \\
\hline AM - State's capital & $\mathrm{R} \$$ & 2,62 & 1,00 & $\mathrm{R} \$ \quad 62,40$ \\
\hline AM - Countryside & $\mathrm{R} \$$ & 4,19 & 1,00 & $\mathrm{R} \$ \quad 93,84$ \\
\hline AP - State's capital & $\mathrm{R} \$$ & 3,90 & 1,14 & $\mathrm{R} \$ \quad 89,40$ \\
\hline AP - Countryside & $\mathrm{R} \$$ & 5,26 & 3,14 & $\mathrm{R} \$ \quad 136,70$ \\
\hline BA - State's capital & $\mathrm{R} \$$ & 1,47 & 0,39 & $\mathrm{R} \$ \quad 33,25$ \\
\hline BA - Countryside & $\mathrm{R} \$$ & 1,61 & 0,39 & $\mathrm{R} \$ \quad 36,18$ \\
\hline CE - State's capital & $\mathrm{R} \$$ & 2,10 & 0,50 & $\mathrm{R} \$ \quad 46,98$ \\
\hline CE - Countryside & $\mathrm{R} \$$ & 3,36 & 0,50 & $\mathrm{R} \$ \quad 72,17$ \\
\hline DF - State's capital & $\mathrm{R} \$$ & 1,21 & 0,39 & $\mathrm{R} \$ \quad 28,18$ \\
\hline ES - State's capital & $\mathrm{R} \$$ & 0,94 & 0,30 & $\mathrm{R} \$ \quad 21,77$ \\
\hline ES - Countryside & $\mathrm{R} \$$ & 1,13 & 0,30 & $\mathrm{R} \$ \quad 25,53$ \\
\hline GO - State's capital & $\mathrm{R} \$$ & 1,19 & 0,39 & $\mathrm{R} \$ \quad 27,63$ \\
\hline GO - Countryside & $\mathrm{R} \$$ & 1,66 & 0,39 & $\mathrm{R} \$ \quad 37,13$ \\
\hline MA - State's capital & $\mathrm{R} \$$ & 1,94 & 0,50 & $\mathrm{R} \$ \quad 43,77$ \\
\hline MA - Countryside & $\mathrm{R} \$$ & 3,10 & 0,50 & $\mathrm{R} \$ \quad 67,03$ \\
\hline MG - State's capital & $\mathrm{R} \$$ & 0,85 & 0,30 & $R \$ 20,04$ \\
\hline MG - Countryside & $\mathrm{R} \$$ & 0,94 & 0,30 & $\mathrm{R} \$ \quad 21,74$ \\
\hline MS - State's capital & $\mathrm{R} \$$ & 1,23 & 0,39 & $\mathrm{R} \$ \quad 28,56$ \\
\hline MS - Countryside & $\mathrm{R} \$$ & 1,73 & 0,39 & $\mathrm{R} \$ \quad 38,42$ \\
\hline MT - State's capital & $\mathrm{R} \$$ & 1,38 & 0,39 & $\mathrm{R} \$ \quad 31,53$ \\
\hline MT - Countryside & $\mathrm{R} \$$ & 1,38 & 0,39 & $\mathrm{R} \$ \quad 31,53$ \\
\hline PA - State's capital & $\mathrm{R} \$$ & 2,28 & 0,91 & $\mathrm{R} \$ \quad 54,76$ \\
\hline PA - Countryside & $\mathrm{R} \$$ & 3,65 & 0,91 & $\mathrm{R} \$ \quad 82,16$ \\
\hline PB - State's capital & $\mathrm{R} \$$ & 1,88 & 0,50 & $\mathrm{R} \$ \quad 42,53$ \\
\hline PB - Countryside & $\mathrm{R} \$$ & 3,00 & 0,50 & $\mathrm{R} \$ \quad 65,04$ \\
\hline PE - State's capital & $\mathrm{R} \$$ & 1,88 & 0,50 & $\mathrm{R} \$ \quad 42,53$ \\
\hline PE - Countryside & $\mathrm{R} \$$ & 2,81 & 0,50 & $\mathrm{R} \$ \quad 61,29$ \\
\hline PI - State's capital & $\mathrm{R} \$$ & 1,94 & 0,50 & $\mathrm{R} \$ \quad 43,77$ \\
\hline PI - Countryside & $\mathrm{R} \$$ & 3,10 & 0,50 & $\mathrm{R} \$ \quad 67,03$ \\
\hline PR - State's capital & $\mathrm{R} \$$ & 0,82 & 0,30 & $\mathrm{R} \$ \quad 19,50$ \\
\hline PR - Countryside & $\mathrm{R} \$$ & 0,91 & 0,30 & $\mathrm{R} \$ \quad 21,15$ \\
\hline RJ - State's capital & $\mathrm{R} \$$ & 1,27 & 0,57 & $\mathrm{R} \$ \quad 31,08$ \\
\hline RJ - Countryside & $\mathrm{R} \$$ & 0,90 & 0,30 & $\mathrm{R} \$ \quad 21,02$ \\
\hline RN - State's capital & $\mathrm{R} \$$ & 1,94 & 0,50 & $\mathrm{R} \$ \quad 43,77$ \\
\hline RN - Countryside & $\mathrm{R} \$$ & 3,30 & 0,50 & $\mathrm{R} \$ \quad 70,90$ \\
\hline RR - State's capital & $\mathrm{R} \$$ & 2,82 & 1,00 & $\mathrm{R} \$ \quad 66,44$ \\
\hline RR - Countryside & $\mathrm{R} \$$ & 4,52 & 1,00 & $\mathrm{R} \$ \quad 100,31$ \\
\hline RS - State's capital & $\mathrm{R} \$$ & 0,95 & 0,30 & $\mathrm{R} \$ \quad 21,93$ \\
\hline RS - Countryside & $\mathrm{R} \$$ & 1,04 & 0,30 & $\mathrm{R} \$ \quad 23,82$ \\
\hline SC - State's capital & $\mathrm{R} \$$ & 0,86 & 0,30 & $\mathrm{R} \$ \quad 20,27$ \\
\hline SC - Countryside & $\mathrm{R} \$$ & 1,04 & 0,30 & $R \$ 23,73$ \\
\hline SE - State's capital & $\mathrm{R} \$$ & 1,59 & 0,50 & $\mathrm{R} \$ \quad 36,84$ \\
\hline SE - Countryside & $\mathrm{R} \$$ & 2,39 & 0,50 & $\mathrm{R} \$ \quad 52,75$ \\
\hline Average freight & & & & $\mathrm{R} \$ 45,29$ \\
\hline
\end{tabular}


DOI: $10.14807 /$ ijmp.v7i5.457

Having as calculation reference the cost table of contracted freight it is possible to calculate directly the average freight cost in $R \$ 45.29$. Using the same table it is practicable to calculate a standard deviation of $R \$ 25.63$, which will lead to an upper limit of $R \$ 70.91$ and a lesser limit of $R \$ 19.66$.

After rationalizing the freight acquisition, a decrease of $44 \%$ in the CTE can be noted, as shown below:

Table 07: Average cost percentage variance

\begin{tabular}{|c|c|c|}
\hline $\begin{array}{l}\text { Average cost for } \\
\text { deliveries with lower } \\
\text { invoices than } R \$ \\
2,000.00 \text { from April to } \\
\text { September } 2014\end{array}$ & $\begin{array}{l}\text { Average cost for } \\
\text { deliveries with lower } \\
\text { invoices than } R \$ \\
2,000.00, \text { using this } \\
\text { work proposal }\end{array}$ & cost variation (\%) \\
\hline 80,81 & 45,29 & $-44 \%$ \\
\hline
\end{tabular}

As shown in Table 08: CTE financial variance of the 10 greatest clients, it is possible to observe the drastic drop in CTE projected on the 10 greatest clients, from $R \$ 50,425.44$ to $R \$ 28,260.60$, generating direct savings of $R \$ 22,164.84$.

Table 08: CTE financial variance of the 10 greatest clients

\begin{tabular}{|c|c|c|c|c|c|}
\hline $\begin{array}{l}\text { Delivery of } \\
\text { invoices with } \\
\text { lower values } \\
\text { than R \$ } \\
2,000.00 \\
\end{array}$ & $\begin{array}{l}\text { Average cost } \\
\text { of delivery } \\
\text { with lower } \\
\text { invoices than } \\
\mathrm{R} \$ 2,000 \text {. } \\
\text { (From April to } \\
\text { September } \\
2014 \text { ) }\end{array}$ & $\begin{array}{l}\text { Average cost } \\
\text { of delivery } \\
\text { with lower } \\
\text { invoices than } \\
\mathrm{R} \$ 2,000 \text {. } \\
\text { (Using this } \\
\text { work } \\
\text { proposal) }\end{array}$ & $\begin{array}{l}\text { Total cost of } \\
\text { delivery with } \\
\text { lower invoices } \\
\text { than } \mathrm{R} \$ \\
2,000.00 \text { for the } \\
\text { top } 10 \text { largest } \\
\text { clients. (From } \\
\text { April to } \\
\text { September } \\
2014 \text { ) }\end{array}$ & $\begin{array}{l}\text { Total cost of } \\
\text { delivery with } \\
\text { lower invoices } \\
\text { than } \mathrm{R} \$ \\
2,000.00 \text { for } \\
\text { the top } 10 \\
\text { largest } \\
\text { clients. (Using } \\
\text { this work } \\
\text { proposal) }\end{array}$ & $\begin{array}{l}\text { Financial } \\
\text { benefits }\end{array}$ \\
\hline 624 & 80,81 & 45,29 & $\$ 50.425,44$ & $\mathrm{R} \$ 28.260,60$ & $\mathrm{R} \$ 22.16$ \\
\hline
\end{tabular}

When comparing total deliveries with invoices lower than $R \$ 2,000.00$ the differences are even more robust: CTE falls from $R \$ 138,185.10$ to $R \$ 77,444.91$, generating savings of $R \$ 60,74019$.

In another comparative analysis with the saved value of $R \$ 60,740.19$ it is possible to make 1,341 deliveries based on the Delivery Average Total Cost of $R \$$ 45.29. This cost reduction, in addition to generating financial results, can also generate level service offers improvement because of the new baseline of more affordable costs. 
Table 09: CTE financial variance of all clients

\begin{tabular}{|c|c|c|c|c|c|}
\hline $\begin{array}{l}\text { Delivery } \\
\text { of } \\
\text { invoices } \\
\text { with } \\
\text { lower } \\
\text { values } \\
\text { than R \$ } \\
2,000.00\end{array}$ & $\begin{array}{l}\text { Average cost } \\
\text { for deliveries } \\
\text { with lower } \\
\text { invoices of } R \$ \\
2,000.00 \text {. } \\
\text { (From April to } \\
\text { September } \\
2014 \text { ) }\end{array}$ & $\begin{array}{l}\text { Average } \\
\text { cost for } \\
\text { deliveries } \\
\text { with lower } \\
\text { invoices of } \\
\mathrm{R} \$ \\
2,000.00 \text {. } \\
\text { (Using this } \\
\text { work } \\
\text { proposal) }\end{array}$ & $\begin{array}{l}\text { Total cost of } \\
\text { deliveries with } \\
\text { lower invoices } \\
\text { R \$ 2,000.00 } \\
\text { (From April to } \\
\text { September } \\
\text { 2014) }\end{array}$ & $\begin{array}{l}\text { Total cost of } \\
\text { deliveries with } \\
\text { lower invoices } \\
\text { R \$ } 2,000.00 \\
\text { (Using this } \\
\text { work } \\
\text { proposal) }\end{array}$ & $\begin{array}{l}\text { Financial } \\
\text { benefits }\end{array}$ \\
\hline 1710 & $\mathrm{R} \$ 80,81$ & 45,29 & $\mathrm{R} \$ 138.185,10$ & $\mathrm{R} \$ 77.444,91$ & $\mathrm{R} \$ 60.740,19$ \\
\hline
\end{tabular}

Another important aspect is the freight weight on the final cost of the product. The average value of invoices lower than $R \$ 2,000.00$ is $R \$ 819.04$ and the average delivery cost is $R \$ 80.91$, representing $9.88 \%$ of the total cost. In case of adopting the new strategy and the average transport cost falls to $R \$ 45.29$, this cost will amount to only $5.53 \%$ of the average cost of invoices lower than $R \$ 2,000.00$. Representing a decrease of $44.03 \%$ of the overall transportation costs of this category of deliveries.

\section{FINAL REMARKS}

Due to the way company $\mathrm{X}$ performs delivery procedures, with no control or logistics alignment, randomly hiring freight and, on many occasions, doing several deliveries to the same customer or to the same region within a short period of time, there is a high cost in this step of the logistics process.

This problem can be mitigated with transports rationalization as proposed and demonstrated earlier, since the implementation of this new working method that includes hiring a predefined logistics partner will require it to optimize the charges, an then to standardize services levels, bringing to cost-benefit improvement and significant reduction on CTE for invoices lower than $R \$ 2,000.00$.

The intention is to use this logistics strategy with all customers and for both types of invoices (lower and higher than $R \$ 2,000.00$ ), this way, with awell-structured procedure and logistics partners adapted to the system, the company may choose to working with closed or fractional loads, respecting the details and peculiarities of each purchase order, being able to choose the most advantageous way.

In this stage of the work, it is possible to assume that the strategic alignment between the company and the carriers will benefit other logistical steps beyond 
transportation. Holding an optimized transportation system it is expected that delays start to decrease, thereby decreasing the need for a safety stock policy so conservative company $\mathrm{X}$ has.

Based on the information and graphics presented in the study, it is concluded that company $X$ has great opportunities for change in its logistics management, which can lead to improvements in its level of service and still generate significant savings that could be reverted to other investments within the organization.

\section{REFERENCES}

BALLOU, R. H. (2014) Logistica empresarial: transportes, administração de materiais e distribuição física. São Paulo: Atlas.

BRAGA, V; CASTILLO, R.(2013) Tipologia e topologia de nós logísticos no território brasileiro: uma análise dos terminais ferroviários e das plataformas multimodais. Boletim Campineiro de Geografia, v. 3, n. 2..

CHRISTOPHER, M. (2007) Logística e Gerenciamento da Cadeia de Suprimentos: criando redes que agregam valor. $2^{\mathrm{a}}$ ed. São Paulo: Thomson lerning.

FERRI, G. L.; CHAVES, G. L. D.; RIBEIRO, G. M. (2015) Análise e localização de centros de armazenamento e triagem de resíduos sólidos urbanos para a rede de logística reversa: um estudo de caso no município de São Mateus, ES. Production, v. 25, n. 1, p. 27-42, jan./mar.

KAMINSKI, L. A. (2004) Propostade uma sistemática de avalição dos custos logísticos da distribuição física - o caso de uma distribuidora de suprimentos industriais. Dissertação (Mestrado em Engenharia de Produção). Universidade Federal do Rio Grande do Sul, Porto Alegre.

LOPES, L. F. L; (2013). Uma análise do ambiente mercadológico de uma empresa do setor mecânico sob perspectivas de Porter. Revista de Administração da UFSM, v.6, n.1, p.103-118, jan./mar.

LUNKES, R. J; SAGAZ, F. R. (2012) Back to Back: Um enfoque na redução dos custos logísticos e tributários. Sociedade, Contabilidae e Gestão. v. 7, n. 1, p.125139.

MINADEO, R.(2012) . Inovações em serviços: adoção do Just in Time pela rede varejista Zara. GEPROS. Gestão da Produção, Operações e Sistemas, Ano 7, nº 1, jan-mar.

MIRANDA, R. F. Q., BEZERRA, M. R., GIGANTE, T. C., DUARTE, D. L.(2014) Impactos da utilização de sistema de informação logístico no compartilhamento de informações na cadeia de suprimento de sobressalentes da Marinha do Brasil. XVII Simpósio de Pesquisa Operacional e Logística da Marinha, Blucher Marine Engineering Proceedings, Volume 1.

OLIVEIRA, J. B.; LEITE, M. S. A.(2010) Modelo analítico de suporte à configuração e integração da cadeia de suprimentos. Gestão da Produção, São Carlos, v. 17, n. 3, p. 447-463. 
OLIVEIRA, R. R.; (2013). Do cerrado mato-grossense para a Amazônia ocidental: os desafios de reduzir os custos logísticos e manter o produto (açúcar) competitivo. Revista Eletrônica de Tecnologia e Cultura, n. 13, p. 182-191, out.

PIANA, J. ERDMANN, R. H.(2011) Fatores geradores de competitividade na manufatura: uma relação entre práticas e resultados. Revista de Administração da UFSM, v.4, n.1, p.73-90, jan./abr.

ROSA, F; OLIVEIRA, L. A. (2010) A importância da logística na formação de custos. Maringá Management: Revista de Ciências Empresariais, v.7, n.1, p. 22-31, jan./jun.

SALGADO, T. T. (2013) Logística: Práticas, técnicas e processo de melhorias. São Paulo: Editora Senac.

SANTOS, L. A. A.; BOTINHA, R. A.; LEAL, E. A. (2013) A contribuição da logística reversa de pneumáticos para a sustentabilidade ambiental. RACE, Unoesc, $v$. 12, n. 2, p. 339-370, jul./dez.

SILVA, M. E.; FIRMO, L. A.; SOUSA, I. G. (2014) Fluxo de materiais numa cadeia de suprimentos: o estudo do manuseio de embalagens em Campina Grande PB. INOVAE - Journal of Engineering and Technology Innovation, São Paulo, v. 2, n. 2, p. 81-99, mai./ago.

SILVEIRA, M. R. (2013) Infraestruturas e logística de transportes no processo de integração econômica e territorial. Mercator, Fortaleza, v. 12, número especial (2)., p. 41-53, set.

SOUZA, D. F.; MARKOSKI, A. (2012) A competitividade logistica do Brasil: um estudo com base na infraestrutura existente. Revista de Administração. FW, v. 10, n. 17.

SOUZA, F. B.; PIRES, S. R. I. (2014) Produzindo para disponibilidade: uma aplicação da Teoria das Restrições em ambientes de produção para estoque. Gestão da Produção, São Carlos, v. 21, n. 1, p. 65-76.

SOUZA, M. A; LEMOS, L. B; ZORZO, L. S.(2014) Comércio tradicional versus comércio eletrônico: um estudo de caso sob o olhar da gestão de custos. Sociedade, Contabilidade e Gestão. Rio de Janeiro. v. 9. n. 2. mai./ago.

VASCONCELLOS, T. C.; MARINS, F. A. S.; JUNIOR, J. M.(2008) Implantação do método activity based costing na logística interna de uma empresa química. Gestão da Produção, São Carlos, v. 15, n. 2, p. 323-335, maio-ago. .

VENTURA, M. M. (2007) O Estudo de Caso como Modalidade de Pesquisa. Revista SOCERJ. Pedagogia Médica, v. 20, n 5; setembro/outubro, p. 383-386.

VITORINO, C. M. (2012) Logística. São Paulo: Pearson Prentice Hall. 